\title{
Ethnic Categorizations in Literature
}

Alec G. Hargreaves

\section{(2) OpenEdition}

\section{Journals}

Electronic version

URL: https://journals.openedition.org/remi/2485

DOI: $10.4000 /$ remi.2485

ISSN: $1777-5418$

\section{Publisher}

Université de Poitiers

\section{Printed version}

Date of publication: 1 June 2005

Number of pages: 19-33

ISBN: 2-911627-40-7

ISSN: 0765-0752

\section{Electronic reference}

Alec G. Hargreaves, "Ethnic Categorizations in Literature", Revue européenne des migrations

internationales [Online], vol. 21 - n² | 2005, Online since 01 October 2008, connection on 14 April 2022

URL: http://journals.openedition.org/remi/2485 ; DOI: https://doi.org/10.4000/remi.2485

This text was automatically generated on 14 April 2022

(c) Université de Poitiers 


\title{
Ethnic Categorizations in Literature
}

\author{
Alec G. Hargreaves
}

1 The study of literature has been heavily conditioned in modern times by nationally defined categories. The structures of university departments, library catalogs publishers' lists and booksellers' shelves all reflect the primacy accorded to national boundaries in the classification of individual writers. Literature grounded in international migration cuts across these familiar boundaries and by the same token risks falling between the cracks of public recognition while at the same time challenging some of the basic assumptions conditioning modern literary studies. The most important challenges of this kind have concerned literary works arising from migratory flows between what we may broadly call the "North" and the "South", umbrella categories which in the present context are defined more by relations of power than by rigid geographical boundaries. Another common way of denoting these categories is in terms of the Center/Periphery model, where the Center ("North") consists of spaces which hold a dominant position in relation to the Periphery ("South"). Until the 1960s, what we now think of the North (or Center) was represented primarily by Western Europe while the South (Periphery) consisted of the empires over which Europeans ruled in Africa, Asia and Oceania. During much of the colonial period, this division had been conceptualized as that between the "West" and the "East", but those terms took on entirely new meaning after the Second World War, when they came to denote the Cold War blocks rivaling each other in the northern hemisphere under American and Soviet leadership. Simultaneously, as Europe's former colonies gained their independence it became common to refer to them as the "Third World", i.e. a relatively poor, disempowered and culturally diverse space mainly in the southern hemisphere distinct from the industrialized capitalist and communist blocs of the North, which in this optic constituted the "first" and "second" worlds. Following the end of the Cold War, with the rise of the notion of "globalization" and the uniquely powerful status of the U.S. as the world's only super-power, the North/South divide now appears as a clearer and more significant geo-political boundary than at any time in the past. The concept of the North incorporates the legacy of European domination and at the same time makes visible the heightened importance of the United States, in 
whose migratory history we can see both a product of and a successor to European colonialism.

2 The problems of literary categorization faced by the United States today as a consequence of recent and past migratory inflows are similar in many ways to those currently faced by West European countries such as France and Britain. In each case, they revolve primarily around immigrant minorities originating in the "South", understood here as a generic term denoting relatively disempowered spaces populated by groups perceived to be of non-European origin. The categories which have emerged in response to the literary phenomena associated with these migratory flows involve complex interrelations between three fundamental strands: ethnic, political and linguistic. The balance between these strands and their relative visibility varies greatly from one category to another. In some cases, (the concepts of "Black" or "African" literature, for example) the ethnic dimension is unmistakable. The political dimension is more visible in categories such as "resistance literature" (Harlow 1987) and "subaltern studies" (Spikavk 1988), while in other instances (the idea of "Francophone" literature, for instance) linguistic criteria are apparently more prominent, though an ethnic dimension is present below the surface. Generally speaking, Anglophone scholars have been more prepared than their French counterparts to openly recognize the ethnic and political issues raised by literatures arising from international migration. At a macro-level, this gap is reflected in the importance accorded in countries such as the United States and Britain to the concepts of postcolonialism and multiculturalism, which have generally been eschewed in France, where the linguistically-based notion of "francophonie" spans related ground but from a very different perspective. At a micro-level, the gap is typified by the growing importance accorded in the United States to categories such as African-American and Latino literatures, in contrast with the marginalization in France of categories such as "Beur" or "banlieue" literatures.

3 The problems of literary categorization arising from migration towards the North cannot be properly understood without first considering those generated during the colonial period by migration to the South. These raised similar ethnic and linguistic issues but in a very different political context. During the colonial period, relatively small settler populations of European origin ruled large "native" populations in the South on whom, in varying degrees, they imposed the languages of the colonial powers. The mixture of ethnic, linguistic and political questions raised by the literatures produced in this context saw the emergence of a number of categories which have subsequently been transferred to and/or transformed in the North in response to the literatures of minorities of non-European migrant origin living in societies populated predominantly by European ethnic groups. In the analysis which follows, I begin by examining categories which emerged during the era of European colonialism before turning to the impact of international migration during the post-colonial period.

\section{The colonial period}

4 The main institutional lines of modern literary studies were laid down during the nineteenth century, which was marked by a growing tide of nationalism within Europe and colonial expansion overseas. Literary history, a major form of literary scholarship during this period, paralleled in many ways the dominance of national narratives in the 
work of nineteenth century historians. Just as historians constructed teleological accounts of the past leading "naturally" to the nation-states in which they lived, so literary scholars took for granted the primacy of national boundaries in demarcating literary spaces. In telling the story of French, German or English literature, literary historians confirmed the apparent naturalness of those boundaries (Bhabha 1990). There were of course exceptions to the insular tendencies implicit in much of this work. Some literary scholars were committed to comparative studies, from which a sub-discipline emerged known as comparative literature (Jost 1974). While outwardlooking at one level, comparative literature nevertheless reinforced at another level the primacy of national categories. It was assumed that for a study to count as comparative, the objects of comparison must come from different national and/or linguistic spaces. The fact that national and linguistic frontiers did not always fully overlap was often overlooked, no doubt in part because it was assumed that the underlying logic of the nation-states which came to dominate the map of Europe during the nineteenth century would eventually lead to neatly isomorphic cultural and political boundaries. "Regional" literatures, i.e. those in languages or dialects squeezed into marginal positions by lack of recognition at the level of the nation-state, were generally considered to be destined to whither and die.

5 In developing some of the early ideas which helped to shape the concept of comparative literature, Goethe formulated the notion of "world literature". As originally conceived by Goethe, "world literature" was at first sight an inclusive concept implying a growing dialogue and sense of community between nations by exchanging the works of their greatest writers. In other respects, however, "world literature" was to prove more narrow in scope, not least because of its elitism. Within Europe, sub-national ("regional") literatures were assumed to have little to contribute to the dialogues between national cultural elites. Overseas, by the end of the nineteenth century most of the world fell under European colonial domination, which branded other cultures as inherently inferior to the civilization of Europe. As many colonized peoples, notably in Africa, were illiterate they were by definition excluded from the table of "world literature" and even civilizations in Asia and elsewhere with long histories of literary production were regarded as marginal players at best. This line of thinking was encapsulated in a remark by the British parliamentarian Thomas Babington Macaulay, according to whom "a single shelf of a good European library was worth the whole native literature of India and Arabia" (Macaulay 1957: 721).

Prior to decolonization, literary categories reflecting the impact of international population movements overseas were heavily Euro-centric. Genres such as travel literature and exoticism represented foreign lands as curiosities and deviations from the European traveler's nationally-rooted norms (Arac and Ritvo 1991, Moura 1992, Hargreaves 1993). The ethnic categories on which they drew were assumed to be unaltered by the cross-cultural contacts engendered by travel. Such writings arose from temporary excursions into foreign lands from which the traveler was expected to return in due course to his or her home country. Excursions of this kind were built on unequal power relations between ethnic groups in which the European traveler enjoyed a privileged status vis-à-vis the foreign peoples whose lands he or she traversed. That status was built in varying degrees on economic power (the traveler could buy his or her way in or out of a foreign place in ways that were not generally available to the local populace) together with diplomatic and/or military protection 
(travel-writers often followed in the wake of colonial conquests, which threw open to outsiders lands which had previously been inaccessible). Permanent settlement overseas in the wake of colonial conquests gave rise to what became generally known as colonial literature, which was initially characterized by three overlapping features: the European ethnicities of its producers, the use of their national languages and their tacit or explicit support for the colonial system (Lebel 1931, Durand 1999). In some cases, colonial literatures took the name of local political entities, overlaid implicitly or explicitly by the linguistic and ethnic domination of the colonizer. This was visibly the case, for example, in the notion of "Anglo-Indian Literature" and more obliquely in labels such as that of the "Algérianistes", writers of European descent in colonial Algeria who positioned their works as a kind of regional variant of the national literature of France (Dunwoodie 1998).

With the growth of educational programs purveying the language and culture of the colonizer, Europeanized "native" elites began to emerge, some of whom took to writing in the language of their colonial masters. There was no immediate recognition of this new ethnic dimension in the literary categories of the time. Works in French or English by African or Asian writers were initially subsumed within the overall category of colonial literature or local variants such as "Anglo-Indian" or "Algérianiste" writing, but this became more problematic when such writers began to question the legitimacy of the colonial system. After the Second World War, as the tide of anti-colonialism gathered momentum, the ethnic origins of writers originating among colonized peoples were recognized in new categories such as "Negro" and "Negro-African" literature, propounded by Africans such as Léopold Sedar Senghor critical of French colonialism with the support of anti-establishment French intellectuals such as JeanPaul Sartre (Senghor 1948). Such categories drew on the concept of "Négritude", first enunciated in the 1930s by the Martinican poet Aimé Césaire (1939). They appealed to what, for present purposes, we may call pan-regional ethnicities (i.e. ethnicities spanning multiple national boundaries, as distinct from smaller, sub-national regional ethnicities). They gained their greatest support during the decades leading up to formal decolonization, when the national boundaries of the post-colonial world were not yet drawn. Decolonization was followed by the rise of new, nationally based literary categories based on the political geography of the newly independent states which replaced the colonial administrative system. While pan-regional categories such as African, Maghrebi (North African) and sub-Saharan African are still sometimes used, these now tend to be seen as conglomerations of national literatures, which have become the most widely used literary categories in post-colonial territories.

Most of these states are profoundly multi-ethnic in character but this is seldom evident at the level of official nomenclature. In regions formerly ruled by France this effacement of internal ethnic differences is reinforced by referring to them as "francophone" countries, implying that the use of French endows them with a transcendent cultural unity. The internal divisions just below the national surface are indirectly hinted at in commonly used labels such as "Francophone Algerian (or Malian or Senegalese) literature" or "Algerian (or Malian or Senegalese) literature of French expression", where the need to qualify a "national" body of literature by naming the language in which it is written reflects the fact that it is by no means the only language spoken in the country concerned. In most so-called francophone countries only the 
educated elites are able to speak and write in French and their populations are often deeply divided by ethnic conflicts reflecting linguistic, religious and other differences.

When first adopted in the early post-colonial period, the "francophone" label not only gave the appearance of attenuating ethnic differences within newly independent states; it also deflected attention at an international level from the political conflicts which had forced France to liquidate her overseas empire. "Francophonie" (literally, the practice of speaking French) and the international movement to which it gave its name focused on the fact that all its practitioners shared the same language, a "gift" of France now voluntarily embraced by writers of countless nationalities around the world. Superficially, this appeared to efface the ethnic and political divisions associated with colonialism, which have been much more evident in the overarching concepts spanning comparable terrain in the Anglophone post-colonial world. The earliest such category was "Commonwealth literature", which soon became criticized as neocolonial in spirit. After brief attempts at replacing it with labels such as "Third World literatures", which were found to suffer from a similar implicit primacy of the "First" (European) world, a wide consensus emerged in favor of the concept of "postcolonial literatures" which were defined by their rejection of European domination (Ashcroft et al. 1989). This terminological instability and the open recognition of the political tensions underlying it has been largely absent from the French-speaking world, where the overarching concept of "francophone literature(s)" has become entrenched during the post-colonial period. Beneath its purely linguistic exterior, seemingly signaling the unity of all literature written in French irrespective of political or ethnic differences among its producers, the concept of "francophone literature" is nevertheless deeply marked by such differences. The literal meaning of "francophone" is simply "Frenchspeaking" or, in the case of a literary text, "written in French". Understood thus, "francophone" literature would embrace all literature written in French, including that produced within metropolitan France. That is not in practice how "francophone" has been understood by most literary scholars. First coined in the nineteenth century by the geographer Onésime Reclus, the word disappeared largely from view until the 1960s, when political leaders of newly decolonized states joined with French officials in using the noun "francophonie" not only as a means of denoting the shared use of the French language inside and outside France but also a rallying point for efforts designed to strengthen that usage. Today, the formally constituted francophone movement, which holds periodic summit meetings of heads of state and of government, spans three main groups of countries: France, former French colonies, and various other states (such as Belgium and Switzerland) in which French is spoken to a significant degree. As a literary category, "francophone" generally has narrower boundaries. It is almost never applied to literature produced within France and while some scholars apply it to writings in French produced in any country outside France (including Europe as well as overseas regions), as most commonly used it is restricted to the literatures of former French colonies. Francophone literature is thus to a large extent the equivalent in the French-speaking world of what, in the Anglophone world, was known for a brief period as Commonwealth literature. Unlike Commonwealth literature and its more politically correct successor, postcolonial literature, francophone literature appears superficially to be less conditioned by political and ethnic divisions. In reality it is as marked by neo-colonialism as the now largely abandoned concept of Commonwealth literature, but has enjoyed much greater longevity. 


\section{The post-colonial period}

10 Just as scholars in France have generally eschewed openly ethnic or political labels (except for those defined by national boundaries) in their categorization of the literatures of former colonial territories, so in their response to the literatures generated by (post-)colonial migrations to the North they have tended to be less accommodating than Anglophone researchers. The most dynamic force in the process of theoretical renewal engendered by South-North migrations has undoubtedly been the United States. Until the Second World War, literary scholars in Europe and the United States shared a largely common set of theoretical tools. In many cases these were forged in Europe before being adopted on the other side of the Atlantic. This was the case, for example, of comparative literature, which after first being theorized in continental Europe became a major institutional feature of American universities. Since the 1960s, scholars in the U.S. have been engaged in a process of radical re-thinking which has often distanced them from their counterparts in Europe, some of whom now appear relatively conservative in outlook. The migratory flows which have stimulated these developments have been of two main types. The U.S. itself has been the primary locus of first of these, while the second has concerned wider population movements associated with the post-war dissolution of Europe's colonial empires. The new forms of thinking associated with both sets of population movements share two important features: they increasingly challenge the established boundaries and components of national literatures and they foreground a realignment of power relations in which hitherto disempowered ethnic groups are accorded levels of respect that were generally lacking in earlier times.

11 The first strand in this realignment, which in the early 1980s became known under the umbrella term of "multiculturalism", arose from the civil rights and related movements which, since the 1950s, had been pressing for Blacks to be accorded greater recognition and equality within the United States. The descendants of forced migrants, they had no realistic prospects of "returning" to ancestral homelands but remained heavily stigmatized within the U.S. Inspired in part by the "Négritude" movement among French-speaking writers and intellectuals originating in the African diaspora, some Americans of African descent were attracted for a time by notions of "Black" and/or "Afro-American" power offering autonomy from white-dominated American society. Their revised official status as fully-fledged members rather than as servants or pariahs of American society was eventually reflected in the emergence of the politically correct term "African American", paralleling longer-established categories such as Anglo-American, Italian American, etc., all of which blend together a shared sense of national membership with the recognition of separate ethnic origins.

Prior to the 1970s, the legacy of slavery followed by a century of segregation had led to the chronic under-representation of African Americans in the nation's educational system. In attempting to redress those imbalances, policies of affirmative action encouraged universities to hire more academics of minority ethnic origin, who in turn pressed for the revision of teaching and research programs, notably in the fields of literature and other cultural forms, so as to accord greater recognition to the work of African American artists. Other minority groups such as Native Americans and, more recently, those originating in Latin America, who now outnumber African Americans, have pressed similar claims with considerable success. A key effect of this has been to 
greatly expand the canon of texts deemed worthy of study. Formerly dominated by writers of European origin, who became caricatured as Dead White Males, university syllabuses have now widened to embrace growing numbers of writers from other ethnic groups.

Changes of this kind are visible not only in the expansion of American literature courses to include works by African American, Latino and other minority ethnic writers and in the creation of entire departments devoted to Black or African American Studies but also in parallel developments in a second major field encompassing European national literatures together with the wider optic of comparative literature. Emblematic of these changes are the revisions undergone by successive editions of the Norton Anthology of World Masterpieces, the most widely used multinational collection of writing in American universities. First published in 1956 (Mack et al. 1956), the anthology is now in its seventh edition. The sub-title of

the first six editions, "Literature of Western Culture", tellingly revealed their Eurocentric bias. Gradually, attempts have been made to correct this imbalance. Beginning with the third edition, published in 1973, a supplement entitled Masterpieces of the Orient was offered as a Companion volume to the main anthology. Since the fifth edition in 1985, a number of non-Western authors have been included in the main anthology. In recognition of this accelerating trend, when the collection entered its seventh edition in 2001 it was, significantly, retitled as the Norton Anthology of World Literature and the sub-title limiting its field to Western Culture was dropped (Lawall 2001). If this re-emergence of the concept of "world literature" still retains, in the Norton anthology, some of the elitist features associated with Goethe's original use of the term (the anthology includes only works of "high" culture and excludes works of popular culture), in other respects it betokens a significant re-alignment of geocultural forces in which African, Asian and other non-European cultures are now taken far more seriously than in the past. Developments of this kind are part of a trend which is increasingly referred to as the "globalizing" of literary studies (PMLA 2001).

Postcolonialism played a key transitional role in this shift from the traditional Eurocentric approach towards a more global view of literature. The collapse of Europe's overseas empires during the early post-war period was marked by the emergence of growing numbers of writers who used the languages of former colonial powers to critique European domination and revalorize the cultures of colonized peoples. In its early stages, much of this literature was sympathetic to the nationalist thrust of independence movements but disillusionment with post-colonial régimes, many of which have been corrupt and authoritarian, soon lessened the credibility of nationalist rhetoric and led many writers into exile. At the same time, post-war Europe has been the site of mass migration from former colonies, leading for the first time to the rise of permanently settled minorities of non-European origin from among whom new literary currents have been emerging. If, as seems likely, postcolonial studies are now being increasingly supplanted by and/or subsumed within the wider problematic of global literary studies, this newer and more encompassing field continues nevertheless to draw on postcolonialism for many of its key concepts, as may be seen from a recent issue of PMLA, the premier journal of literary studies in the Anglophone world. In his Introduction to a special issue of PMLA on "The Globalizing of Literary Studies", the guest editor, Giles Gunn, noted that "the language of literary study has changed witness the new governance of such terms as hybridity, diaspora, transculturation, subaltern, hegemony, deterritorialization, rhizome, mestizo, Eurocentrism, and 
"othering" (Gunn 2001: 18). This list is remarkable not only because most of these terms, identified by Gunn as part of the agenda of globalized literary studies, first came to prominence in the field of postcolonial studies but also because they ignore or cut across nationally defined categories, emphasizing processes of cultural mixing which open up new ethnic categories or which defy categorization altogether. At least three factors have contributed to this trend: a growing recognition of the fact that colonialism, traditionally thought of almost literally in terms of a black and white pattern of ethnic relations, engendered numerous forms of cultural interaction and change in the overseas empires; the personal trajectories of migration and exile experienced by many writers originating in former colonies, generating transnational perspectives in place of monolithic nationalism; and the permanent settlement of postcolonial minorities within the national heartlands of former colonial powers, leading to new forms of transcultural writing within Europe.

While concepts such as "subaltern", "hegemony" and "Eurocentrism" evoke the bipolar asymmetrical power relations associated with colonialism, the notion of "deterritorialization" (borrowed by Anglophone scholars from the work of French theorists Gilles Deleuze and Félix Guattari) denotes the challenge to such relations raised by postcolonialism, while "hybridity", "diaspora", "transculturation" and "mestizo" all speak of the crossing and erosion of cultural and political boundaries, a process which, when pushed to its extreme, can defy categorization altogether, a tendency exemplified in the figure of the "rhizome" (another term borrowed from Deleuze and Guattari). After a first wave of postcolonial writing which worked more or less in parallel with the political project of national liberation, the more recent trend has been for postcolonial literature to become a "writing which foregrounds and celebrates a national or historical rootlessness" (Boehmer 1995: 239-240), typified by the concept of "nomadism". Developed initially with reference to postcolonial writing in English, approaches of this kind have been increasingly applied to Francophone literatures by scholars based in Anglophone countries (Miller 1998). Typical of this trend was a special issue of Yale French Studies (1993) entitled "Post/Colonial Conditions: Exiles, Migrations and Nomadisms". More recently, the literatures of postcolonial minorities within Europe have been approached through categories borrowed or adopted from the Anglophone world. Paul Gilroy's concept of the "Black Atlantic" (Gilroy 1993), typical of the transnational hybrid categories which have come to the fore in Anglophone literary scholarship, has been adapted in the recent notion of "Blackening Europe" (Raphael-Hernandez 2004), while other scholars now speak of the "Browning" of Europe (Baadqir 2003, Parati forthcoming). All of these concepts speak of processes of cultural mixing in which conventionally defined national categories are seen as increasingly blurred or irrelevant.

In the French-speaking world, the region which has been most open to transnational literary categories is undoubtedly the Caribbean. This was where Aimé Césaire conceived the concept of Négritude, where Edouard Glissant (1981) later propounded the idea of "Antillanité" and where, more recently, a new generation of writers has argued for a literature of "Créolité" (Bernabé et al. 1993). Where the first of these concepts foregrounded a diasporic concept of ethnicity and the second proposed a panregional geo-political frame of reference, the third was characterized primarily as a space of linguistic mixing. What all three have in common is the low salience accorded to nationally defined spaces. The most important reason for this no doubt lies in the extreme form taken by European colonialism in the Caribbean, where indigenous 
cultures were obliterated, forced migrants were severed from their ancestral homelands in Africa and European languages became creolized through intercourse between highly diverse ethnic groups. The proponents of "Créolité" define it as "the interactional or transactional aggregate of Caribbean, European, African, Asian, and Levantine cultural elements, united on the same soil by the yoke of history" (Bernabé et al. 1993: 87). Inherently hybrid, this condition implies the "annihiliation of false universality, of monolinguism, and of purety" and the championing of "the indeterminacy of the new" as a consequence of which "full knowledge of Creolness will be reserved for Art" (Bernabé et al. 1993: 90). The hybridity and indeterminacy at the heart of such concepts are incompatible with the fixity of national boundaries and challenge the habits of mind of scholarly institutions which have been accustomed to taking such boundaries as basic frames of reference.

Where, within the overarching distinction between "French" and "Francophone" literatures, does the literature of the French-speaking Caribbean belong? Some see it as "francophone" and by the same token separate from the literature of France. If this determination fits with the juridical status of a territory such as Haïti, which has been independent for two hundred years, it is problematic where Martinique and Guadeloupe are concerned, for in international law they are part of France. In line with this, an alternative vision sees the literatures produced in these overseas départements as regional variants within French (as distinct from Francophone) literature. Neither approach seems entirely satisfactory, for the binary logic of the French/francophone divide (and the nationally-based distinctions which underlie it) is fundamentally at odds with the fact that these literatures are at one and the same time both inside and outside the literature of France.

18 Similar problems are posed by the classification of writers who have migrated to France or who were born there of migrant parents. France has a long history of incorporating in its national literature the works of writers born in other parts of Europe. To cite only a few examples in the post-war period, Samuel Beckett, Eugène Ionesco and Andreï Makine are all regarded as French writers, though they were born respectively in Ireland, Romania and Russia. By contrast, writers born in former French colonies who have migrated to France are generally classified as "francophone" rather than French even when, as for example in the cases of Léopold Sedar Senghor and Tahar Ben Jelloun, they take French citizenship. Here again we see how, beneath the linguistic surface of the "francophone" label, the political legacy of colonialism continues to play a major role in the categorization of writers.

Distinctions of this kind are still more striking in the case of writers born in France of immigrant parents. Emile Zola was the son of an Italian immigrant but he is never referred to as anything other than a French writer. Authors such as Azouz Begag and Ahmed Kalouaz, born in France of Algerian immigrants, are seldom referred to simply as "French", though France is in a literal sense their home country and most of them hold French citizenship. Unlike second-generation Europeans, who have generally been absorbed invisibly into French society and culture, second-generation North Africans have attracted a series of labels distinguishing them from the majority ethnic population. The earliest of these was "Beur", a backslang expression formed by inverting and partially truncating the syllables of "Arabe". Early discussions of "Beur" literature and culture during the 1980s (Hargreaves 1989) were followed in the 1990s by the emergence of a new category, "banlieue" culture (Hargreaves 1999), which while not 
explicitly articulated in terms of ethnicity served in fact as a coded label for cultural currents closely associated with post-colonial minorities concentrated in socially disadvantaged neighborhoods (the "banlieues"). While these labels have been widely used in the media, they have been less easily incorporated in the institutional structures of literary studies, where national lines of demarcation have remained primordial. Should "Beur" writers be studied in university departments of French or do they belong rather in departments of comparative literature or other organizational units focusing on literatures other than that of France? In practice, where they have become the objects of scholarly study, this has generally been in teaching and research units focusing on "francophone" authors, i.e. those generally regarded as non-French despite their writing in the French language. Yet it is far from clear that this categorization fits with the thrust of their work.

At least three different schools of thought have developed concerning the location of "Beur" literature. The first of these argues that "Beur" literature is simply an extension of the national literatures of the "home" countries in the Maghreb. This line of thinking is typified in the following remark by an official of the Amicale des Algériens en Europe, set up by the authorities in Algeria to monitor and assist the expatriate population in France: 'Il n'y aura jamais de culture "beur" au sens élaboré du terme. Il y a une culture algérienne en France qu'il faut sans cesse développer.' (Bouchedda 1988). This is not so much a cultural description as a political statement, expressing the desire of the Algerian authorities to keep the Algerian diaspora within the orbit of the "home" country. Scholars such as Charles Bonn, who has played an important role in affording recognition to "Beur" writers via "francophone" programs of study, recognizes that nationally-defined literatures provide ill-suited frames of reference for the works of such authors. While including a selection of "Beur" writers in an anthology of Algerian literature which he edited in 1990, he remarks that they probably did not belong in it "for most of them feel only a distant relationship with the culture of their parents and are more invested in forms of identity based in the 'banlieues' [i.e. disadvantaged areas] of Europe's major urban spaces, where ethnic or cultural 'origins' are often displaced by feelings of marginality which have little in common with established definitions of identity" (Bonn 1990: 227).

21 A second school of thought sees "Beur" writers as far more deeply immersed in the culture of France - more truly their "home" country, since it is there that they have been born and educated - than in the culture of their parents. For this reason Abdallah Mdarhri-Alaoui contrasts them with francophone authors raised and resident in the Maghreb, who are much more deeply marked by Arabo-Berber culture. In the works of second-generation Maghrebis in France, "the Arabo-Berber cultural dimension is reduced to mere traces, often limited to 'working class (oral) culture'. [...] It would be fairer to see these writers as 'new French writers', if we are forced to label them" (Mdarhri-Alaoui 1995: 42).

22 A third approach, advanced primarily by scholars based in Anglophone countries, sees these authors as engaged in a cultural project that is trans- or anti-national in spirit. Thus Mireille Rosello argues that the driving force behind Beur culture is "rather than a dream of integration[,] of belonging, [...] the assertion of one's right to 'désappartenir' (not to belong)" (Rosello 1993: 23). Similarly, Martine Delvaux has analysed the ways in which second-generation Maghrebis use "l'ironie comme un procédé stylistique dont l'effet consiste à décentraliser la notion d'identité nationale". Delvaux argues 
that humour and irony are used as distancing devices through which secondgeneration Maghrebis "cherchent à désappartenir de l'identité qu'on leur impose"; their aim is to "échapper à la réification du sujet (post-)colonisé - en l'occurence beur - par le sujet (post-)colonial - en l'occurence français (et peut-être plus globalement, européen)" (Delvaux 1995: 681). In developing these ideas, Delvaux draws on the work of post-colonial theorists such as Homi Bhabha (1994), from whom she borrows the notion of a "third space" transcending the binary opposites (in this case, France and the Maghreb) to which hybrid cultural practices are too often reduced.

While these writers certainly aim to widen conventional notions of Frenchness to include elements reflecting the ethnic diversity resulting from international migration, they do not generally seek to position themselves outside French society or culture. On the contrary, one of their main preoccupations has been with establishing the legitimacy of their presence within France. For this reason, they have tended to reject their categorization as "Beur" writers on the grounds that this is a marginalizing category denying them recognition as French writers in the full sense (Reynaert 1993).

Similar issues have marked the debates over Latino literatures in the United States (Zimmerman 1992, Candelaria et al. 2004).Should these be recognized as autonomous literatures outside the dominant (Anglo-centric) literature of the U.S., as extensions of the national literatures of the countries in which Latino minorities have their origins (Mexico, Cuba, etc.) or as new components within U.S. literature? Granted the hybrid nature of these new literatures, it makes little sense to force such debates into either/ choices. Chicano literature (i.e. literature produced by writers of Mexican origin within the U.S.) stands simultaneously in at least three literary spaces: that of Mexico, that of the U.S. and that of Latino minorities within the U.S. This simultaneous presence in multiple spaces reflects the impact of international migration in stimulating the emergence of new literary movements which cannot be fully understood if they are forced into conventionally defined nationally categories.

\section{Conclusion}

North-South migration during the colonial period appeared to leave established literary categories relatively untouched. The political structures of colonialism were such that European cultures were assumed to remain largely unaffected by contact with the cultures of colonized peoples. Postcolonialism has brought a threefold change: writers of non-European origin have used the languages of their former colonizers to challenge the dominance of the North in its dealings with the South, analysts of colonial discourse have shown it to be more permeated by cultural mixing than had previously been thought, and South-North migration has brought new forms of hybridity into the cultural heartland of the North. In mapping these changes, new literary categories have emerged which traverse national boundaries and erode their traditional dominance in literary scholarship. While the ethnic dimensions of these changes have been embraced more readily by scholars in the Anglophone world, they are present in more camouflaged ways in Francophone studies and the logic of globalization is such that they appear destined to become ever more evident. 


\section{BIBLIOGRAPHY}

ARAC Jonathan and Harriet RITVO Eds (1991) Macropolitics of Nineteenth Century Literature. Nationalism, Exoticism, Imperialism. Philadelphia, University of Pennsylvania Press.

ASHCROFT Bill, Gareth GRIFFITHS and Helen TIFFIN eds (1989) The Empire Writes Back: Theory and Practice in Post-Colonial Literatures, London, Routledge.

BAADQIR Rashad A. (2003) The Browning of Europe: Multicultural Challenges and Perspectives of a Changing Europe. Philadelphia, Xlibris.

BERNABE Jean, Patrick CHAMOISEAU et Raphaël CONFIANT (1993). éloge de la créolité. Edition bilingue français/anglais. Texte traduit par M.B. Taleb-Khyar, Paris, Gallimard.

BHABHA Homi K. (1994) The Location of Culture, London/New York, Routledge.

BHABHA Homi K. ed. (1990) Nation and Narration, London/New York, Routledge.

BOEHMER Elleke (1995) Colonial and Postcolonial Literature: Migrant Metaphors, Oxford/New York, Oxford University Press.

BONN Charles (1990) Anthologie de la littérature algérienne (1950-1987). Paris, Livre de poche.

BOUCHEDDA Ahcène (1988) Culture, au diapason de l'Algérie, Actualité de l'émigration, 29 juin, p.

26.

CANDELARIA Cordelia Chávez, et al. eds (2004) Encyclopedia of Latino Popular Culture Westport, Connecticut, Greenwood.

CESAIRE Aimé (1939) Cahier d'un retour au pays natal, Volontés, n² 201, août.

DELVAUX Martine (1995) L'Ironie du sort, le tiers espace de la littérature beure, French Review, vol. 68, no. 4, March, pp. 681-692.

DUNWOODIE Peter (1998) Writing French Algeria, Oxford, Clarendon Press.

DURAND Jean-François ed. (1999) Regards sur les littératures coloniales, Paris: L'Harmattan, 3 vols, 3 vols.

GILROY Paul (1993) The Black Atlantic: Modernity and Double Consciousness, London, Verso.

GLISSANT Edouard (1981) Le Discours antillais, Paris, Seuil.

GUNN Giles (2001) “Introduction: Globalizing Literary Studies”, in PMLA, vol. 116, no. 1, January, pp. 16-31.

HARGREAVES Alec G. (1989) Voices from the North African Immigrant Community in France: Immigration and Identity in Beur Fiction, Oxford/New York, Berg.

HARGREAVES Alec G. (1993) Immigration and Travel: Literary Antitheses?, New Comparison, $\mathrm{n}^{\circ}$ 16, Autumn 1993, pp. 120-129.

HARGREAVES Alec G. (1999) No Escape? From “cinéma beur" to the "cinéma de la banlieue", in Ernspeter Rühe (ed.), Die Kinder der Immigration/Les enfants de l'immigration, Würzburg, Königshausen \& Neumann, pp. 115-228.

HARLOW Barbara (1987) Resistance Literature, New York, Methuen.

JOST François (1974) Introduction to Comparative Literature, Indianapolis, Pegasus. 
LAWALL Sarah ed. (2001) The Norton Anthology of World Literature, 7 vols. New York, Norton.

LEBEL Roland (1931) Histoire de la littérature coloniale en France. Paris, Larose.

MACAULAY Thomas Babington (1957) "Minute of 2 February 1835 on Indian Education”, Macaulay, Prose and Poetry, selected by G.M. Young. Cambridge, MA: Harvard University Press.

MACK Maynard et al. eds (1956) The Norton Anthology of World Masterpieces, 2 vols. New York, Norton.

MDARHRI-ALAOUI Abdallah (1995) Place de la littérature "beur" dans la production francomaghrébine, in Charles Bonn éd., Littératures des immigrations, vol. 1, Un espace littéraire émergent, Paris, L'Harmattan, pp. 41-50.

MILLER Christopher L. (1998) Nationalists and Nomads: Essays on Francophone African Literature and Culture, Chicago, University of Chicago Press.

MOURA Jean-Marc (1992) Lire l'exotisme, Paris, Dunod.

PARATI Graziella (forthcoming) Minor Italy: The Art of Talking Back, Toronto, University of Toronto Press.

PMLA (2001) “Globalizing Literary Studies”, vol. 116, n 1, January.

RAPHAEL-FERNANDEZ Heike ed. (2004) Blackening Europe: The African American Presence, New York/London, Routledge.

REYNAERT François (1993) Y a-t-il une culture beur? Le Nouvel Observateur, 2 décembre.

ROSELLO Mireille (1993) The "Beur Nation": Toward a Theory of 'Departenance', Research in African Literatures, vol. 24, n 3, Fall, pp. 13-24.

SENGHOR Léopold Sedar ed. (1948) Anthologie de la nouvelle poésie nègre et malgache de langue française, précédé de "Orphée noir" de Jean-Paul Sartre, Paris, Presses Universitaires de France.

SPIVAK Gayatri Chakravorty (1988) Can the Subaltern Speak?, in Cary Nelson and Lawrence Grossberg eds, Marxism and the Interpretation of Culture, Houndmills, Macmillan Education, pp. 271-313.

YALE FRENCH STUDIES (1993) Post/Colonial Conditions: Exiles, Migrations and Nomadisms" nº 82.

ZIMMERMAN Marc (1992) U.S. Latino Literature: An Essay and Annotated Bibliography, Chicago, Abrazo Press.

\section{ABSTRACTS}

Anglophone scholars have generally been more prepared than their French counterparts to openly recognize the ethnic and political issues raised by literatures arising from international migration. At a macro-level, this gap is reflected in the importance accorded in countries such as the United States and Britain to the concepts of "postcolonialism" and "multiculturalism", which have generally been eschewed in France, where the linguistically-based notion of "francophonie" spans related ground but from a very different perspective. At a micro-level, the gap is typified by the growing importance accorded in the United States to categories such as African-American and Latino literatures, in contrast with the marginalization in France of categories such as "Beur" or "banlieue" literatures.

Les catégories ethniques dans la littérature.

Les chercheurs anglophones se sont montrés plus prêts que leurs homologues français à 
reconnaître ouvertement les dimensions ethniques et politiques des littératures issues des flux migratoires internationaux. Sur le plan des concepts de base, ce contraste se manifeste dans l'importance accordée aux Etats-Unis et en Grande-Bretagne aux notions du " postcolonialisme » et $\mathrm{du}$ "multiculturalisme», termes qui sont généralement récusés en France, où l'idée de la «francophonie » marque une approche théorique très différente à des phénomènes littéraires similaires. Plus concrètement, cette disjonction se traduit aux États-Unis dans l'importance croissante de catégories littéraires telles que «Afro-Américains» ou «Latinos", alors qu'en France les littératures dites « Beur » ou « de banlieue » sont marginalisées.

\section{Las categorías étnicas en la literatura.}

Los investigadores anglófonos se mostraron mas preparados que sus homólogos franceses para reconocer francamente las dimensiones étnicas y políticas de las literaturas resultantes de los flujos internacionales. En el nivel macro este contraste se nota comparando a la importancia dada en Estados-Unidos y en Gran Bretaña a nociones como "postcolonialismo" o "multiculturalismo", términos generalmente rechazados en Francia, donde el tema de la francofonía abre una perspectiva muy diferente sobre fenómenos literarios similares. Mas concretamente, este contraste aparece claramente comparando la importancia creciente que dan los investigadores anglófonos a categorías literarias como Latinos o Afro-Americanos mientras que las literaturas llamadas "beur" o "de los suburbios" siguen marginalizadas en Francia.

\section{INDEX}

Mots-clés: littérature, représentations

\section{AUTHOR}

\section{ALEC G. HARGREAVES}

Director, Winthrop-King Institute for Contemporary French and Francophone Studies, Florida State University, Tallahassee, Florida 32306-1515, USA. Mail : ahargrea@mailer.fsu.edu 